\title{
Lipopolysaccharide and porin of Roseobacter denitrificans, confirming its phylogenetic relationship to the $\alpha-3$ subgroup of Proteobacteria
}

\author{
Uwe Neumann, ${ }^{1}$ Hubert Mayer, ${ }^{2}$ Emile Schiltz, ${ }^{3}$ Roland Benz ${ }^{4}$ \\ and Jürgen Weckesser ${ }^{1}$
}

Author for correspondence: Jürgen Weckesser. Tel: +49 761203 2638. Fax: +497612032647.

\footnotetext{
1 Institut für Biologie II, Mikrobiologie,

Schănzlestraße 1, D-79104

Freiburg, Germany

2 Max Planck Institut für Immunbiologie, Stübeweg 51, D-79108 Freiburg, Germany

3 Institut for Organische Chemie und Biochemie, Albertstraße 21, D-79104 Freiburg, Germany

4 Lehrstuhl für Biotechnologie, Biozentrum der Universităt Würzburg, Am Hubland, D-97074 Wärzburg. Germany
}

\begin{abstract}
Roseobacter denitrificans has rough ( $R$ )-type lipopolysaccharide, containing 2-keto-3-deoxyoctonate but no heptoses. Its lipid A has a glucosaminecontaining, phosphorylated backbone. It contains the rare 3-oxotetradecanoic (3-oxomyristic) acid as the only amide-bound fatty acid and ester-bound 3-hydroxydecanoic acid, this pattern being characteristic for the $\alpha$-3 subgroup of Proteobacteria. Treatment of the major outer-membrane protein (porin, apparent molecular mass $88 \mathrm{kDa}$ ) of Roseobacter denitrificans with EDTA $\left(2 \mathrm{mM}, 30{ }^{\circ} \mathrm{C}, 20 \mathrm{~min}\right.$ ) resulted in the dissociation of the oligomers into monomers (apparent molecular mass $35 \mathrm{kDa}$ ). EDTA-sensitive dissociation has so far been observed only within the $\alpha$-3 subgroup of Proteobacteria. The 12 N-terminal amino acids of the monomers exhibit sequence homology with the porins of Rhodobacter capsulatus, Rhodobacter sphaeroides and Rhodopseudomonas blastica. Renaming of Roseobacter denitrificans as Rhodobacter denitrificans is suggested.
\end{abstract}

Keywords: Roseobacter denitrificans, lipopolysaccharide, porin, $\alpha-3$ subgroup of Proteobacteria, phylogeny

\section{INTRODUCTION}

Aerobic photosynthetic bacteria which contain bacteriochlorophyll $a$ have been found in different ecological niches (Shiba et al., 1991; Fuerst et al., 1993; Yurkov \& van Gemerden, 1993). They are represented by several genera such as the marine Erytbrobacter (Shiba \& Simidu, 1982) and Roseobacter (Shiba, 1991), the freshwater Erytbromicrobium (Yurkov et al., 1992), Roseococcus (Yurkov \& Gorlenko, 1992) and Porpbyrobacter (Fuerst et al., 1993), as well as some species of Metbylobacterium (Sato, 1987) and Rbizobium (Evans et al., 1990). All orange- and pinkpigmented obligately aerobic bacteria were originally included in one genus - Erythrobacter - with the type species Erytbrobacter longus (Shiba \& Simidu, 1982). Due to the taxonomic heterogeneity of this group, the pinkcoloured strains were separated from Erytbrobacter to

Abbreviations: DOC, sodium deoxycholate; KDO, 2-keto-3-deoxyoctonate (3-deoxy-D-manno-2-octulosonate); LDAO, N,N-dimethyldodecylamine $N$-oxide. form a new genus - Roseobacter - with the two representatives Roseobacter denitrificans and Roseobacter litoralis (formerly Erytbrobacter sp. OCh 114 and OCh 149) (Shiba, 1991).

Within the phylogenetic tree, the aerobic photosynthetic bacteria containing bacteriochlorophyll $a$ are combined with the anaerobic or facultatively anaerobic photosynthetic bacteria into the $\alpha$-subgroup of Proteobacteria (Stackebrandt et al., 1988; Woese et al., 1984). By 16S rRNA sequence analysis it was demonstrated that the species of Erythrobacter, Erythromicrobium and Porphyrobacter belong to the $\alpha-4$ and Roseococcus to the $\alpha-1$ subclass, the latter being moderately related to Rhodopila globiformis and Thiobacillus acidophilus. Roseobacter belongs to the $\alpha-3$ subclass (Fuerst $e t$ al., 1993), of which prominent members are Rhodobacter capsulatus, Rhodobacter sphaeroides and Paracoccus denitrificans.

Data on lipopolysaccharide (LPS) and porin from aerobic photosynthetic bacteria have not hitherto been available. In this work, LPS and porin of Roseobacter denitrificans were characterized. The data confirm the assignment of 
Roseobacter denitrificans to the $\alpha-3$ subclass of Proteobacteria.

\section{METHODS}

Cultivation of bacteria. Roseobacter denitrificans was taken from the strain collection of the Institut für Biologie II, Mikrobiologie, Freiburg i. Br., FRG. Mass cultures were grown aerobically in the dark at $32{ }^{\circ} \mathrm{C}$ according to Shioi (1986).

Isolation of LPS. LPS was isolated by the hot phenol-water procedure (Westphal \& Jann, 1965) and sedimented three times by preparative ultracentrifugation in distilled water $(105000 \mathrm{~g}$, $4^{\circ} \mathrm{C}, 4 \mathrm{~h}$ ). The extraction was repeated with the lyophilized pellet of the third centrifugation step. The final pellet, representing the LPS, was lyophilized.

Analytical methods. Sodium deoxycholate polyacrylamide gel electrophoresis (DOC-PAGE) was performed according to Komuro \& Galanos (1988). Fatty acids were liberated by transesterification with conc. $\mathrm{HCl} /$ methanol $(1: 5, \mathrm{v} / \mathrm{v})$ at $85^{\circ} \mathrm{C}$ for $18 \mathrm{~h}$ and determined by combined gas liquid chromatography-mass spectrometry (GC-MS, Hewlett Packard HP 5988 A). The fatty acid methyl esters were separated on a fused silica capillary column DB 1 (length $15 \mathrm{~m}$, i.d. $0.25 \mathrm{~mm}$ ). Mass spectra were taken at $70 \mathrm{eV}$ in the mass range $43-$ $400 \mathrm{Da} \mathrm{s}^{-1}$. For quantification, the fatty acid methyl esters were separated by gas-liquid chromatography (GLC; Varian Aerograph, model 3300 ) on an FFAP column [ $5 \%$ on Chromosorb, 80-100 mesh, length $1.8 \mathrm{~m}$, i.d. $2 \mathrm{~mm}$, with a temperature programme ranging from 150 to $200^{\circ} \mathrm{C}$ ( $5 \mathrm{~min}$ initial temperature then with a ramp rate of $\left.\left.2{ }^{\circ} \mathrm{C} \mathrm{min}^{-1}\right)\right]$. Ester- and amide-linked fatty acids were liberated by hydroxylaminolysis (Snyder \& Stephens, 1959). Neutral sugars, liberated by $0.1 \mathrm{M}$ $\mathrm{HCl}$ at $100^{\circ} \mathrm{C}$ for $48 \mathrm{~h}$, were identified and quantified as their alditol acetate derivatives by GLC (Varian Aerograph, model 3700) on a fused silica capillary column DB 225 (length $30 \mathrm{~m}$, i.d. $0 \cdot 25 \mathrm{~mm}$ ). For GC-MS analysis a Supelco SP 2380 capillary column was used. Mass spectra were taken at $70 \mathrm{eV}$ in the mass range 43-400 $\mathrm{Da} \mathrm{s}^{-1}$. Amino sugars and amino acids, released by $4 \mathrm{M} \mathrm{HCl}$ at $100^{\circ} \mathrm{C}$ for $18 \mathrm{~h}$, were identified and quantified by combined amino acid/amino sugar analysis. The amino sugars were also identified as alditol acetates by GLC on a Poly A-103 column (length $1.8 \mathrm{~m}$, i.d. $2 \mathrm{~mm}, 3 \%$ on Gaschrom Q, 100-200 mesh using a temperature programme from 200 to $260^{\circ} \mathrm{C}$, $5 \mathrm{~min}$ initial time followed by a ramp rate of $2^{\circ} \mathrm{C} \mathrm{min}^{-1}$ ). Uronic acids were released by $0.5 \mathrm{M} \mathrm{H}_{2} \mathrm{SO}_{4}$ at $100^{\circ} \mathrm{C}$ for $4 \mathrm{~h}$ and separated by high-voltage electrophoresis at $3 \mathrm{kV}(80-120 \mathrm{~mA}$ and $4{ }^{\circ} \mathrm{C}$ for $3 \mathrm{~h}$ ) in a solvent system (pyridine/formic acid/ acetic acid/water, $1: 1 \cdot 5: 10: 90$, by vol.) of $\mathrm{pH} 2 \cdot 8$. The electropherograms were stained with naphthoresorcinol according to Partridge (1948). 2-Keto-3-deoxyoctonate (KDO) was liberated by $1 \mathrm{M} \mathrm{H}_{2} \mathrm{SO}_{4}$ at $100^{\circ} \mathrm{C}$ for $30 \mathrm{~min}$ and separated by highvoltage electrophoresis as described above except that the running time was reduced to $2 \mathrm{~h}$. The electropherograms were stained with the periodate/thiobarbituric acid reagent according to Brade \& Galanos (1983). Sialic acids were determined according to Yao et al. (1989); phosphorus was assayed according to Lowry et al. (1954).

Isolation of porin and determination of its sensitivity to EDTA. The cells were collected by centrifugation, washed with buffer $\left(20 \mathrm{mM}\right.$ Tris/ $\left.\mathrm{HCl}, \mathrm{pH} 8.0 ; 10 \mathrm{mM} \mathrm{MgCl}_{2}\right)$ and resuspended in the same buffer. DNase, RNase and phenylmethylsulfonyl fluoride were added and the cells disrupted by a Bühler homogenizer (type Vi2) for $25 \mathrm{~min}$. The homogenate was centrifuged at $28300 \mathrm{~g}$ for $1 \mathrm{~h}$ and washed once with the same buffer as above. The sediment (crude envelope fraction) was extracted twice with $2 \%(\mathrm{v} / \mathrm{v})$ Triton-X-100, $10 \mathrm{mM}$ $\mathrm{MgCl}_{2}, 20 \mathrm{mM}$ Tris $/ \mathrm{HCl}, \mathrm{pH} 8.0$, at $40^{\circ} \mathrm{C}$ and at $38^{\circ} \mathrm{C}$ for $40 \mathrm{~min}$ for the isolation of the cell wall according to Schnaitman (1971). The oligomeric porin was obtained from the cell wall fraction by extraction with $2 \%$ (w/v) N,N-dimethyldodecylamine $N$-oxide(LDAO), $0 \cdot 01 \%$ (v/v)2-mercaptoethanol, $0.5 \mathrm{M} \mathrm{NaCl}, 10 \%$ (v/v) glycerol, $10 \mathrm{mM} \mathrm{MgCl}_{2}, 20 \mathrm{mM}$ Tris $/ \mathrm{HCl}, \mathrm{pH} 8.0$, at $38^{\circ} \mathrm{C}$ for $70 \mathrm{~min}$. After centrifugation $\left(170000 \mathrm{~g}, 4^{\circ} \mathrm{C}, 60 \mathrm{~min}\right)$ the supernatant enriched with the porin was dialysed against $0.08 \%$ (w/v) LDAO, $20 \mathrm{mM} \mathrm{NaCl}$, $2 \mathrm{mM} \mathrm{NaN}, 20 \mathrm{mM}$ Tris/ $\mathrm{HCl}, \mathrm{pH} 8.0$ (buffer A of the subsequent anion-exchange chromatography) for $15 \mathrm{~h}$. Aliquots of the dialysed supernatant were applied on a Mono P HR 5/5 anion-exchange-chromatography column (Pharmacia). To remove photopigments the column was washed with $10 \mathrm{ml} 1 \%$ (w/v) LDAO, $4 \%$ (w/v) betaine, $20 \mathrm{mM} \mathrm{NaCl}, 2 \mathrm{mM} \mathrm{NaN}_{3}$, $20 \mathrm{mM}$ Tris $/ \mathrm{HCl}, \mathrm{pH} 7 \cdot 8$. Subsequently the column was eluted with a linear salt gradient of $0.02-1 \mathrm{M} \mathrm{NaCl}$ in $30 \mathrm{ml}$ at a flow rate of $1 \mathrm{ml} \mathrm{min}^{-1}$ with an FPLC system (Pharmacia). For further purification the porin obtained by this procedure was applied on a Superose 12 HR 10/30 gel-permeationchromatography column (Pharmacia) and eluted with $0.08 \%$ (w/v) LDAO, $300 \mathrm{mM} \mathrm{LiCl,} 2 \mathrm{mM} \mathrm{NaN}_{3}, 20 \mathrm{mM}$ Tris/HCl, $\mathrm{pH} 7 \cdot 8$.

For determination of EDTA-sensitivity, porin purified by ionexchange gel-permeation chromatography was incubated with SDS-PAGE sample buffer containing $2-10 \mathrm{mM}$ EDTA for 30 min at room temperature. Subsequently a $0.1 \mathrm{M} \mathrm{CaCl}$ solution was added to one half of the samples in a 1:1 ratio to see whether the dissociation into monomers was reversible. All samples were incubated for another $30 \mathrm{~min}$ at room temperature and finally applied directly onto SDS-PAGE (see below).

SDSPAGE. Discontinuous SDS-PAGE was performed using $14 \%(w / v)$ acrylamide slab gels. Gels were stained with Coomassie R-250.

$\mathrm{N}$-terminal sequence determination of porin. The $\mathrm{N}$-terminal sequence of hexane/propan-2-ol-precipitated porin was determined by Edman degradation in a pulsed liquid protein sequencer model 477A (Applied Biosystems) equipped with a PTH-amino acid analyser type 120A (Applied Biosystems). Homology studies were made on the $12 \mathrm{~N}$-terminal residues. The following amino acids were regarded as homologous: S,T / D,E / V,I,F,L,M,Y / A,P,G / K,R,H.

\section{RESULTS}

\section{Isolation of LPS and lipid A}

The LPS from Roseobacter denitrificans was isolated by two sequential phenol-water extractions and obtained from the water phase in a yield of $0.4 \%$ of cell dry mass. It was classified as rough (R)-type LPS, since it migrated as a single band in DOC-PAGE. When compared with several R-type LPSs of Salmonella minnesota, the LPS of Roseobacter denitrificans had a migration pattern similar to that of an $\mathrm{R}_{\mathrm{c}}$-mutant of Salmonella minnesota.

The lipid A moiety was split off from the LPS by mild acid hydrolysis $\left(1 \%, \mathrm{v} / \mathrm{v}\right.$, acetic acid, $\left.80^{\circ} \mathrm{C}, 100 \mathrm{~min}\right)$. The yield of lipid A was $8 \%(w / w)$ of the LPS dry mass, that of the polysaccharide moiety $59 \%(w / w)$. Fatty acid analysis of lipid A revealed 3-hydroxydecanoic acid and 3oxotetradecanoic (3-oxomyristic) acid in a molar ratio of 10:8 (the small amounts of 18:1 detected were considered as contamination). 3-Hydroxydecanoic acid was exclus- 
Table 1. Chemical composition of the LPS, lipid A and polysaccharide fraction of Roseobacter denitrificans

\begin{tabular}{|c|c|c|c|}
\hline \multirow[t]{2}{*}{ Component } & \multicolumn{3}{|c|}{ Content (nmol $\mathrm{mg}^{-1}$ ) in: } \\
\hline & LPS & Lipid A & $\begin{array}{c}\text { Polysaccharide } \\
\text { fraction }\end{array}$ \\
\hline Ribose & 16.9 & ND & $15 \cdot 1$ \\
\hline Arabinose & $5 \cdot 5$ & ND & $9 \cdot 4$ \\
\hline Mannose & $24 \cdot 8$ & ND & $83 \cdot 4$ \\
\hline Glucose & $39 \cdot 2$ & ND & $65 \cdot 3$ \\
\hline Glucosamine & $238 \cdot 5$ & $385 \cdot 0$ & - \\
\hline Glucosamine 6-phosphate & $39 \cdot 8$ & $11 \cdot 2$ & - \\
\hline Glycine & $27 \cdot 4$ & $57 \cdot 2$ & $22 \cdot 9$ \\
\hline Alanine & $0 \cdot 7$ & - & $1 \cdot 0$ \\
\hline Hexuronic acids & - & ND & ND \\
\hline $\mathrm{KDO}$ & + & ND & ND \\
\hline Phosphate & ND & 1330 & ND \\
\hline 3-Hydroxydecanoic acid & $2 \cdot 7$ & $774 \cdot 4$ & ND \\
\hline 3-Oxotetradecanoic acid & $4 \cdot 0$ & $953 \cdot 1$ & ND \\
\hline
\end{tabular}

ND, Not determined; - , not present; + , present, but not quantified.

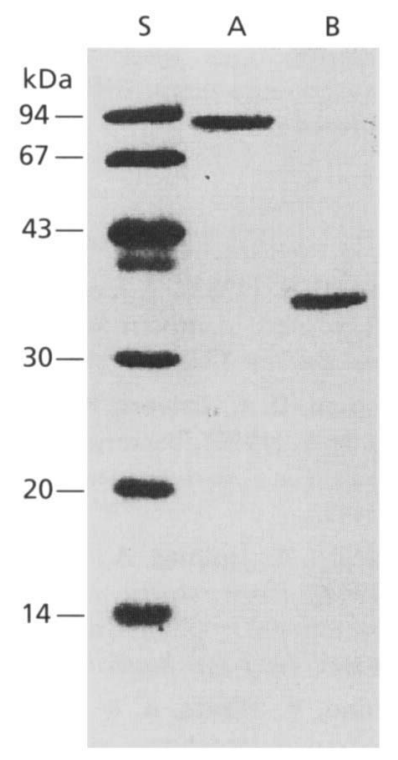

Fig. 1. SDS-PAGE of porin released from outer membranes of Roseobacter denitrificans. Lanes: A, porin solubilized at $30^{\circ} \mathrm{C}$ for $20 \mathrm{~min}$; B, porin solubilized at $100^{\circ} \mathrm{C}(5 \mathrm{~min}) ; \mathrm{S}$, molecular mass markers. The separating gel contained $14 \%$ acrylamide. Gels were run at a constant voltage of $150 \mathrm{~V}$. Staining: Coomassie brilliant blue.

ively ester-bound, and 3-oxotetradecanoic acid amidebound, as determined by hydroxylaminolysis (Table 1 ). GC-MS analysis of the $N$-acetylated alditol acetates of the amino sugars revealed glucosamine but no diaminoglucose or any other amino sugar. The lipid A contained high amounts of phosphate. Small amounts of glycine and

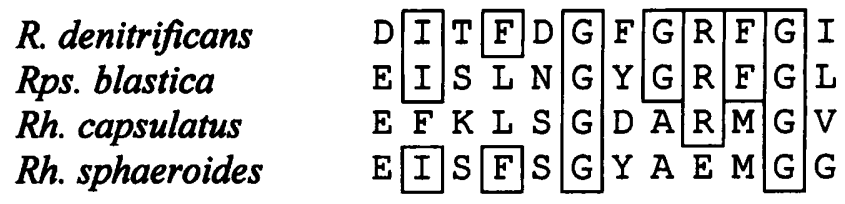

Fig. 2. Alignment of the $\mathrm{N}$-terminal ends of the porins from Roseobacter denitrificans, Rhodopseudomonas blastica (Kreusch et al., 1994), Rhodobacter capsulatus (Schiltz et al., 1991) and Rhodobacter sphaeroides (Woitzik et al., 1990). Identical amino acids are boxed.

traces of glucosamine 6-phosphate were also detected. The polysaccharide fraction (degraded polysaccharide) contained alanine and glycine but no glucosamine. As tested by high-voltage electrophoresis the LPS contained KDO. $N$-Acetylneuraminic acid was absent. In agreement with the R-character, neutral sugars were found only in small amounts. Two pentoses, ribose and arabinose, and two hexoses, glucose and mannose, but no heptoses were detected by GC-MS of the alditol acetate derivates. Uronic acids, examined by high-voltage electrophoresis and subsequent naphthoresorcinol staining, were not observed.

\section{EDTA sensitivity and $\mathrm{N}$-terminal amino acid sequence of porin}

The porin of Roseobacter denitrificans migrated in SDSPAGE as a single band with an apparent molecular mass of $88 \mathrm{kDa}$. The addition of $2 \mathrm{mM}$ EDTA to the SDSPAGE sample buffer caused a complete dissociation into monomers with an apparent molecular mass of $35 \mathrm{kDa}$ at room temperature. Subsequent addition of $\mathrm{CaCl}_{2}$ led to reaggregation into the oligomeric form.

The porin was purified by anion-exchange chromatography and gel-filtration chromatography; purity was checked by SDS-PAGE (Fig. 1) and N-terminal sequence determination. Gas-phase sequencing revealed the $12 \mathrm{~N}$ terminal residues as follows: $\mathrm{NH}_{2}$-Asp-Ile-Thr-Phe-AspGly-Phe-Gly-Arg-Phe-Gly-Ile. Side-sequences were not observed. The $\mathrm{N}$-terminal sequences of porins from other bacteria were compared for homology studies (Fig. 2). Significant sequence homology was found to porins of Rhodopseudomonas blastica ( $91 \%$ identical or conservative exchanged amino acids), to Rhodobacter capsulatus (75\% identical or conservative exchanged amino acids), and to Rhodobacter sphaeroides ( $83 \%$ identical or conservative exchanged amino acids). No sequence homology (less than $25 \%$ ) was found to bacteria that do not belong to the $\alpha-3$ subgroup of Proteobacteria except a $58 \%$ homology to Omp 1 from Neisseria species.

\section{DISCUSSION}

LPSs, especially their lipid A component, have been shown to reflect phylogenetic relationships between many Gram-negative bacteria (Weckesser \& Mayer, 1988; Mayer et al., 1989). This has been found to be true also for 
the $\alpha-3$ subgroup of Proteobacteria, where the fatty acid pattern has proven to be a valuable phylogenetic marker. The lipid A of Roseobacter denitrificans contains the same fatty acid pattern as the other species of the $\alpha-3$ subgroup. It includes the rare 3-oxotetradecanoic acid, which is amide-bound in both Roseobacter denitrificans and Rhodobacter capsulatus 37b4 (Krauss et al., 1989); in Rhodobacter sphaeroides 3-oxotetradecanoic acid is accompanied by amide-bound 3-hydroxytetradecanoic acid (Salimath et al., 1983). All these species have 3-hydroxydecanoic acid as the main ester-linked fatty acid (Weckesser \& Mayer, 1988). Rhodopseudomonas blastica, recently described to belong also to the $\alpha-3$ subgroup of Proteobacteria (Kawasaki et al., 1993), has the same characteristic fatty acid spectrum of amide-linked 3oxotetradecanoic acid and ester-linked 3-hydroxydecanoic acid (Tegtmeyer et al., 1985). The main sugar component of the LPS of Roseobacter denitrificans is phosphorylated glucosamine, which originates from lipid A. All species of the $\alpha-3$ subgroup so far studied have phosphorylated lipid $A_{\text {GlcN }}$ (Weckesser \& Mayer, 1988). In other subgroups of the $\alpha$-group there are species possessing nonphosphorylated lipid As, such as lipid $\hat{A}_{\text {DAG }}$ (Weckesser \& Mayer, 1988) in Rhodopseudomonas viridis and Rhodopseudomonas palustris or lipid $\mathrm{A}_{\mathrm{GlcN}}$ in Rhodomicrobium vannielii (Mayer \& Weckesser, 1984). The LPS of Roseobacter denitrificans - and that of Rhodopseudomonas blastica - contain no heptoses, otherwise widespread as a characteristic core constituent of many Gram-negative bacteria. The lack of heptoses in the LPS is another characteristic of the bacteria of the $\alpha-3$ subgroup of Proteobacteria (Weckesser et al., 1995).

The porin of Roseobacter denitrificans could be dissociated into monomers by EDTA-containing SDS-PAGE sample buffer at room temperature. This characteristic has been found so far only with porins of Rhodobacter capsulatus, Rhodobacter sphaeroides and Paracoccus denitrificans, all of which are members of the $\alpha-3$ subgroup. Porins have recently been classified into ten groups according to their protein sequences (Schiltz et al., 1991). Rhodobacter capsulatus has so far been taken as the only member of the tenth group with homology values to the other groups that correspond those to the randomized sequence of Rhodobacter capsulatus. In the present study, homology of the Roseobacter denitrificans porin with those of all ten groups was tested. The comparison was performed with the $12 \mathrm{~N}$-terminal amino acids, forming directly the first transmembrane strand. According to the model obtained with the porin of Rbodobacter capsulatus (Weiss et al., 1991), the $\beta$-strands spanning the outer membrane are believed to have rather conservative amino acid sequences. Good homology was found with porins of all species of the $\alpha-3$ subgroup tested. Most interestingly, it was especially high ( $91 \%$ identical or conservative exchanged amino acids) to the porin of Rhodopseudomonas blastica, the structure of which is also known at atomic resolution (Kreusch et al., 1994). On the other hand, the homology values were less than $25 \%$ identical or conservative exchanged amino acids to porins from bacteria not belonging to the $\alpha-3$ subgroup, except to Omp 1 from Neisseria meningitidis and
Neisseria gonorrboeae (each having $58 \%$ identical or conservative exchanged amino acids). Neisseria species are members of the $\beta$-3 subgroup of Proteobacteria (Woese, 1987 ), the LPS of the latter-mentioned species containing $\beta$-hydroxydecanoic acid among others; 3-oxotetradecanoic acid was not found in this earlier study, but only one column and no mass spectrometry was used for fatty acid identification (Stead et al., 1975).

The reported homology of porins within the $\alpha-3$ subgroup of Proteobacteria may be taken as another indication of the phylogenetic relationship between Roseobacter denitrificans and the other bacteria of this subgroup. Together with the characteristics of the LPS, the homology of cytochrome $c_{551}$ and the $\mathrm{B}_{870}$ polypeptides in comparison to those of Rhodobacter capsulatus (Okamura et al., 1987, Liebetanz et al., 1991), and the 16S rRNA data, it now seems to be proved that Roseobacter denitrificans belongs to the $\alpha-3$ subgroup of Proteobacteria. Accepting the considerations for Rhodopseudomonas blastica (Tegtmeyer et al., 1985; Kawasaki et al., 1993), renaming of Roseobacter denitrificans as Rhodobacter denitrificans would be the consequence.

\section{ACKNOWLEDGEMENTS}

The authors acknowledge detailed help by Dr W. Yurkov in refining the manuscript. This work was supported by the Deutsche Forschungsgemeinschaft (SFB176, B9) and the Fonds der Chemischen Industrie.

\section{REFERENCES}

Brade, H. \& Galanos, C. H. (1983). A method to detect 2-keto-3deoxyoctonate and related compounds on pherograms and chromatograms. Anal Biochem 132, 158-159.

Evans, W. R., Fleishman, D. E., Calvert, H. E., Pyaty, P. V., Alter, G. M. \& Subba Rao, N. S. (1990). Bacteriochlorophyll and photosynthetic reaction centers in Rbizobium strain BTAi1. Appl Environ Microbiol 56, 3445-3449.

Fuerst, J. A., Hawkins, J. A., Holmes, A., Sly, L. I., Moore, C. J. \& Stackebrandt, E. (1993). Porphyrobacter neustonensis gen. nov., sp. nov., an aerobic bacteriochlorophyll-synthesizing budding bacterium from fresh water. Int J Syst Bacteriol 43, 125-134.

Kawasaki, H., Hoshino, Y., Hirata, A. \& Yamasato, K. (1993). Is intracytoplasmic membrane structure a generic criterion? It does not coincide with phylogenetic interrelationships among phototrophic purple nonsulfur bacteria. Arch Microbiol 160, 358-362.

Komuro, T. \& Galanos, C. (1988). Analysis of Salmonella LPS by sodium deoxycholate-polyacrylamide gel electrophoresis. J Chromatogr 450, 381-387.

Krauss, J. H., Seydel, U., Weckesser, J. \& Mayer, H. (1989). Structural analysis of the nontoxic lipid A of Rbodobacter capsulatus 37b4. Eur J Biochem 180, 519-526.

Kreusch, A., Neubuser, A., Schiltz, E., Weckesser, J. \& Schulz, G. E. (1994). Structure of the membrane channel porin from Rhodopseudomonas blastica at $2 \cdot 0 \AA$ A resolution. Protein Sci 3, 58-63.

Liebetanz, R., Hornberger, U. \& Drews, G. (1991). Organization of the gene coding for the reaction center $L$ and $M$ subunits and $B_{\mathbf{8 7 0}}$ antenna polypeptides $\alpha$ and $\beta$ from the aerobic photosynthetic bacterium Erythrobacter sp. OCh 114. Mol Microbiol 5, 1459-1468. 
Lowry, O. H., Roberts, N. R., Kuner, K. Y., Wu, N. L. \& Farr, A. L. (1954). The quantitative histochemistry of brain. Chemical methods I. $J$ Biol Chem 207, 1-17.

Mayer, H. \& Weckesser, J. (1984). 'Unusual' lipid A's : structures, taxonomical relevance and potential value for endotoxin research. In Handbook of Endotoxin, vol 1, Chemistry of Endotoxin, pp. 221-247. Edited by E. Th. Rietschel. Amsterdam: Elsevier.

Mayer, H., Masoud, H. Urbanik-Sypniewska, T. \& Weckesser, J. (1989). Lipid A composition and phylogeny of Gram-negative bacteria. Bull Jpn Fed Cult Collect 5, 19-25.

Okamura, K., Miata, T., Iwanaga, S., Takamia, K. \& Nishimura, M. (1987). Complete amino acid sequence of cytochrome $c_{551}$ from Erytbrobacter species strain OCh 114. J Biochem 101, 957-966.

Partridge, S. M. (1948). Filter-paper partition chromatography of sugars. 1. General description and application to the qualitative analysis of sugars in apples, egg white and foetal blood of sheep. Biochem J 42, 238-250.

Salimath, P. V., Weckesser, J., Strittmatter, W. \& Mayer, H. (1983). Structural studies on the non-toxic lipid A from Rhodopseudomonas sphaeroides ATCC 17023. Eur J Biochem 136, 195-200.

Sato, K. (1987). Bacteriochlorophyll formation by facultative methylotrophs, Protaminobacter ruber and Pseudomonas AM1. FEBS Lett 85, 207-210.

Schiltz, E., Kreusch, A., Nestel, U. \& Schulz, G. E. (1991). Primary structure of porin from Rhodobacter capsulatus. Eur I Biochem 199, 587-594.

Schnaitman, C. A. (1971). Solubilization of the cytoplasmic membrane of Escherichia coli by Triton X-100. J Bacteriol 108, 545-552.

Shiba, T. (1991). Roseobacter litoralis gen. nov. sp. nov. and Roseobacter denitrificans sp. nov., aerobic pink-pigmented bacteria which contain bacteriochlorophyll a. Syst Appl Microbiol 14, 140-145.

Shiba, T., Shioi, Y., Takamiya, K., Sutton, D. C. \& Wilkinson, C. R. (1991). Distribution and physiology of aerobic bacteria containing bacteriochlorophyll $a$ on the East and West coasts of Australia. Appl Environ Microbiol 57, 295-300.

Shiba, T. \& Simidu, U. (1982). Erytbrobacter longus gen. nov., sp. nov., an aerobic bacterium which contains bacteriochlorophyll $a$. Int J Syst Bacteriol 32, 211-217.

Shioi, Y., (1986). Growth characteristics and substrate specifity of aerobic photosynthetic bacterium Erytbrobacter sp. (OCh 114). Plant Cell Physiol 27, 567-572.

Snyder, F. \& Stephens, N. (1959). A simplified spectrophotometric determination of ester groups in lipids. Biochim Biopbys Acta 34, 244-245.

Stackebrandt, E., Murray, R. G. E. \& Trüper, H. G. (1988). Proteobacteria classis nov., a name for the phylogenetic taxon that includes the "purple bacteria and their relatives". Int J Syst Bacteriol 38, 312-325.

Stead, A., Main, J. S., Ward, M. E. \& Watt, P. J. (1975). Studies on lipopolysaccharides isolated from strains of Neisseria gonorrboeae. J Gen Microbiol 88, 123-131.

Tegtmeyer, B., Weckesser, J., Mayer, H. \& Imhoff, J. F. (1985). Chemical composition of the lipopolysaccharides of Rhodobacter sulfidophilus, Rhodopseudomonas acidophila and Rhodopseudomonas blastica. Arch Microbiol 143, 32-36.

Weckesser, J. \& Mayer, H. (1988). Different lipid A types in lipopolysaccharides of phototrophic and related non-phototrophic bacteria. FEMS Microbiol Rev 54, 143-154.

Weckesser, J., Mayer, H. \& Schulz, G. E. (1995). Anoxygenic phototrophic bacteria: model organisms for studies on cell wall macromolecules. In Anoxygenic Photosynthetic Bacteria. Edited by R. E. Blankenship, M. T. Madigan \& C. E. Bauer. Dordrecht: Kluwer (in press).

Weiss, M. S., Abele, U., Weckesser, J., Welte, W., Schiltz, E. \& Schulz, G. E. (1991). Molecular architecture and electrostatic properties of a bacterial porin. Science 254, 1627-1630.

Westphal, O. \& Jann, K. (1965). Bacterial lipopolysaccharides, extraction with phenol/water and further application of the procedure. Methods Carbobydr Chem 5, 83-91.

Woese, C. R. (1987). Bacterial evolution. Microbiol Rev 51, 221-227. Woese, C. R., Stackebrandt, E., Weisburg, W. G., Paster, B. J., Madigan, M. T., Fowler, V. J., Hahn, C. M., Blanz, P., Gupta, R., Nealson, K. H. \& Fox, G. E. (1984). The phylogeny of the purple bacteria: the alpha subdivision. Syst Appl Microbiol 5, 315-326.

Woitzik, D., Weckesser, J., Benz, R., Stevanovic, S., Jung, G. \& Rosenbusch, J. P. (1990). Porin of Rhodobacter capsulatus: biochemical and functional characterization. $Z$ Naturforscb $45 c$, 576-582.

Yao, K., Ubuka, T., Masuoka, N., Kinuta, N. \& Ikeda, T. (1989). Direct determination of bound sialic acids in sialoglycoproteins by acidic ninhydrin reaction. Anal Biocbem 179, 332-335.

Yurkov, V. \& Gorlenko, V. M. (1992). A new genus of freshwater aerobic bacteriochlorophyll a-containing bacteria, Roseococcus gen. nov. Microbiology 60, 628-632.

Yurkov, V., Gorlenko, V. M. \& Kompantseva, E. I. (1992). A new type of fresh water orange-colored bacterium Erythromicrobium gen. nov. Microbiology 61, 169-172.

Yurkov, V. \& van Gemerden, H. (1993). Abundance and salt tolerance of obligately aerobic, phototrophic bacteria in a microbial mat. Netherlands J Sea Res 31, 57-62.

Received 15 November 1994; revised 11 April 1995; accepted 19 April 1995. 